\title{
ANALYSIS OF HISTOPATHOLOGY AND HEAVY METALS CONTENTS OF CADMIUM (Cd) IN TILAPIA (OREOCHROMIS NILOTICUS) IN DOWNSTREAM AT THE REJOSO RIVER OF PASURUAN REGENCY, EAST JAVA, INDONESIA
}

\author{
Aini Riang Nadiya Nur \\ Master's Study Program, Department of Aquaculture, Faculty of Fisheries and Marine \\ Science, University of Brawijaya, Indonesia \\ Herawati Endang Yuli \\ Department of Aquatic Resource Management, Faculty of Fisheries and Marine Science, \\ University of Brawijaya, Indonesia \\ Maftuch \\ Department of Aquaculture, Faculty of Fisheries and Marine Science, \\ University of Brawijaya, Indonesia \\ *E-mail: riangnadiya25@gmail.com
}

\begin{abstract}
The river is one of the water media susceptible to the pollution of harmful pollutant substances, one of which is the heavy metal Cadmium $(\mathrm{Cd})$. As a result of the large amount of Cd content that enters the river body has an impact on decreasing water quality conditions and disrupting fish health. Histopathological observations in fish are significant to know the picture of fish health through structural changes in organ tissues. The research was carried out in March-April 2021 at the Lower Rejoso River, Pasuruan. The method used survey method with descriptive data analysis. Samples were taken three times with a period of 2 weeks at three different stations. Parameters observed included histopathology of gills, kidneys, and liver of tilapia (Oreochromis niloticus). Heavy metal $\mathrm{Cd}$ in water and fish organs, physical and chemical parameters of water including temperature, $\mathrm{pH}, \mathrm{DO}$, and COD. The results of histopathological analysis obtained types of damage to the organs of tilapia, namely cell degeneration, necrosis, congestion, and hyperplasia with mild-moderate impact. Observation results of heavy metal $\mathrm{Cd}$ in water and tilapia organs have exceeded the specified quality standards. The results of the measurement of physical and chemical parameters of water are still optimal for fish growth. Based on these results, it can conclude that the increasing amount of histopathological damage to fish organs was in line with the high levels of $\mathrm{Cd}$ heavy metal in the waters and fish organs.
\end{abstract}

\section{KEY WORDS}

Water quality, pollution, degeneration, congestion, necrosis.

The river is a natural water source that has an important role and provides many benefits for human life and other living things [1]. Anthropogenic activities around the river that occur significantly pollute and reduce the quality of river water, especially human and industrial activities. It produce domestic wastes, industrial wastes, and use hazardous chemicals [2]. The Rejoso River is one of the major rivers in Pasuruan Regency, East Java which flows and empties into the Madura Strait. There are lot of industrial activities in the area downstream of the Rejoso River as sugar factories and MSG [3]. These conditions can pollute the river ecosystem and disrupt the natural structure of the river [4].

Heavy metal is one of the pollutants found in river waters. The heavy metal content of Cadmium (Cd) in the water and body of organisms indicates the presence of heavy metal sources originating from nature and human activities [5]. The decline in river water quality that occurs due to heavy metal Cd pollution can reduce the ecological balance of the waters and trigger structural and functional damage to fish organs [6] [7]. Fish can be used as 
bioindicators of water pollution because fish can react to physical changes in water and other polluting compounds [8]. Tilapia (Oreochromis niloticus) is a fish found in the waters of the Lower Rejoso River. Tilapia can survive changes in certain environmental conditions [9].

Changes that occur both at the cellular and tissue levels are the basis for histopathological analysis. The histopathological analysis was used to describe the health of fish through structural changes in organs, the main targets of contaminants such as gills, kidneys, and liver [10] [11]. The types of damage that often occur in the gills, kidneys and liver are necrosis, degeneration, congestion and hyperplasia [12]. This study aimed to analyze the histopathological damage to the gills, kidneys, and liver of tilapia (Oreochromis niloticus) and heavy metal content of Cadmium (Cd) in the Lower Rejoso River, Pasuruan Regency, East Java.

\section{MATERIALS AND METHODS OF RESEARCH}

This research was conducted in March-April 2021 downstream at Rejoso River, Pasuruan, East Java. The method used is a survey method with descriptive data analysis. Determination of the location of sampling and measurement of water quality is used purposive sampling method based on land use. There are three different locations, station one is in industrial and residential areas, station two is in aquaculture, and plantation areas, and station three is in rice fields and near the estuary.

Samples of tilapia (Oreochromis niloticus) were obtained from fisherman using handline fishing gear. Fish samples will be surgically removed and the gills, kidneys, and liver are taken for microscopic analysis. The method used to make histology preparations is the paraffin method and Haemotoxylin-Eosin (HE) staining at the Anatomy and Histology Laboratory, Faculty of Medicine, Universitas Brawijaya. The method used to measure the concentration of heavy metal Cadmium (Cd) is Automic Absorption Spectrophotometry (AAS) at the Chemistry Laboratory, Faculty of Mathematics and Science, Universitas Brawijaya. Water quality parameters measured directly in the field include physics (temperature) and chemistry ( $\mathrm{pH}$ and Dissolved Oxygen/DO) the same time, Chemical Oxygen Demand (COD) parameters were analyzed at the Jasa Tirta I Laboratory, Malang.

Observational data are analyzed descriptively. Histopathological observations on the gills, kidneys, and liver of tilapia were compared with histopathological results of tilapia under normal conditions. Data on Cd heavy metal levels in water and water quality data were compared with Water Quality Criteria based on Class III Government Regulation of the Republic of Indonesia Number 22 of 2021 [13]. Analysis of heavy metal content in fish organs compared with the quality standard of SNI 7387:2009 concerning Maximum Limits of Heavy Metal Contamination in Food [14].

\section{RESULTS AND DISCUSSION}

Histopathological observation structures in fish have been widely carried out because they can be used as biomarkers of fish stress and monitoring fish health. The main organ target of heavy metal exposure are gills, kidneys, liver, and flesh [15]. Based on histopathological observations on the gills, kidneys, and liver of tilapia (Oreochromis niloticus) downstream in Rejoso River. Several of the damage found in the form of necrosis, cell degeneration, hyperplasia, and congestion. The types of damage that generally occur in fish organ tissues due to exposure to pollutants are in the form of edema, lamella fusion, hyperplasia, necrosis, degeneration, congestion, and hypertrophy [16].

Histopathological analysis results of tilapia (Oreochromis niloticus) gills was carried microscopically from each station are as follows (Table 1).

Based on the observation results made, the highest level of gill tissue damage is found at station 1 with a damage percentage of $51.22 \%$ with moderate damage status, while the lowest gill tissue damage is at station 2 with a damage percentage of $45.78 \%$ with mild damage statuses. Based on the results of the analysis failure status. It indicates that the gills of tilapia (Oreochromis niloticus) in the waters of the Lower Rejoso River that damaged due 
to exposure to pollutants. One of them is heavy metal $\mathrm{Cd}$. Gills are respiratory organs that become the first target of defilement because they are directly related to waters that indicate to be polluted [17].

Table 1 - Histopathological Scoring of Tilapia (Oreochromis niloticus) Gills

\begin{tabular}{llllll}
\hline \multirow{2}{*}{ Station } & Damage & & & & \\
\cline { 2 - 5 } & Necrosis & Degeneration & Hyperplasia & Average $(\%)$ & Damage Status \\
\hline 1 & 25.33 & 72.33 & 56.00 & 51.22 & Moderate \\
2 & 21.67 & 61.67 & 54.00 & 45.78 & Mild \\
3 & 25.33 & 69.33 & 56.33 & 50.33 & Moderate \\
\hline
\end{tabular}

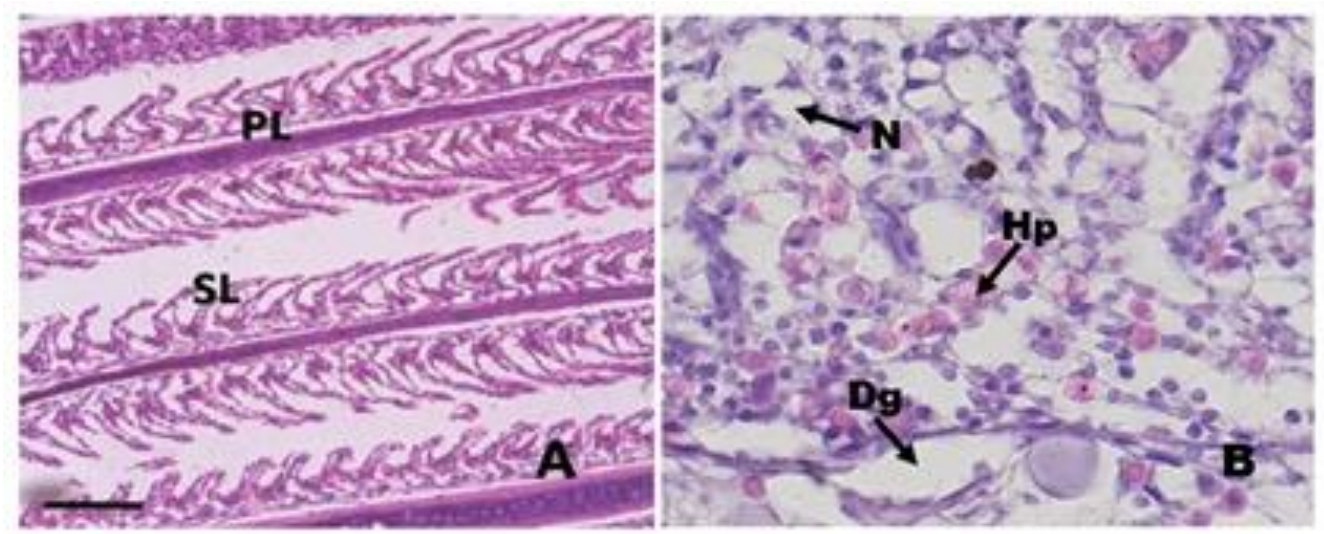

Figure 1 - Normal histology of gills (A) [18] ; Tilapia histology gills damaged by necrosis $(\mathrm{N})$, cell degeneration (Dg), hyperplasia (Hp) (B) (Source: Research documentation)

In the gills tissues structure generally, the primary lamellae (PL) and secondary lamellae (SL) are still clearly visible (Figure 1A). Meanwhile, the results of observations on the structure of the gill organs exposed to heavy metal $\mathrm{Cd}$ obtained types of damage in the form of necrosis, cell degeneration, and hyperplasia (Figure 1B). Histopathological observations on gill utilize as biomarkers in assessing the level of pollution of the aquatic environment. Most of the damage to the gill tissue is the outcome of pollutant entry such as insecticides and heavy metals also poor water quality conditions [15]. Several types of damage to the gill tissue are necrosis (cell death), edema (swelling), hyperplasia (formation of excessive cell tissue) [19].

Histopathological analysis result of tilapia (Oreochromis niloticus) kidneys was carried microscopically from each station are as follows (Table 2).

Table 2 - Histopathological Scoring of Tilapia (Oreochromis niloticus) Kidney

\begin{tabular}{llllll}
\hline \multirow{2}{*}{ Station } & Damage & & & Average $(\%)$ & Damage Status \\
\cline { 2 - 4 } & Necrosis & Degeneration & Congestion & & Moderate \\
\hline 1 & 26.00 & 68.33 & 64.33 & 52.89 & Mild \\
3 & 19.00 & 66.67 & 60.00 & 48.56 & Mild \\
\hline
\end{tabular}

Based on the observation result was made, the highest level of damage to kidney tissue is found at station 1 with a harm percentage of $52.89 \%$ with moderate damage status, while the lowest damage to gill tissues is at station 2 with a damage percentage of $48.56 \%$ with mild damage statuses. Based on the results of the analysis of the damage status. It indicates that the kidneys of tilapia (Oreochromis niloticus) in the waters of the Lower Rejoso River that damaged due to exposure to pollutants, one of which was heavy metal Cd. The kidney's function is filtering and excreting materials do not need by the fish body such as heavy metals. Therefore, the kidneys are often damaged histologically as a toxicant 
substance result [20]. Heavy metal contamination and poor water quality can cause changes in tubules and glomerulus [21].

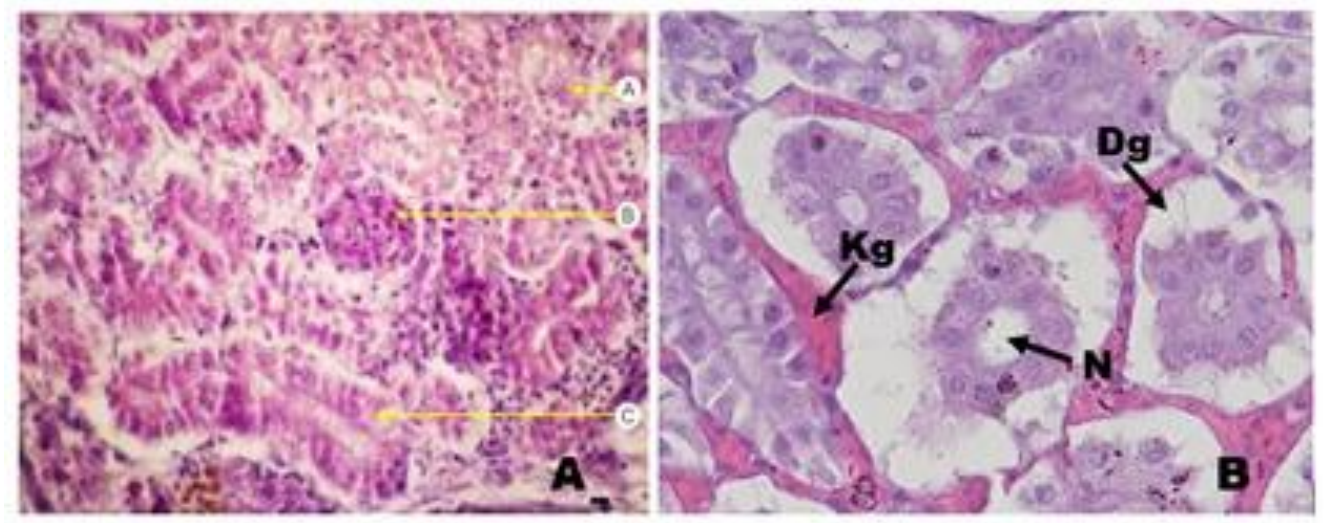

Figure 2 - Normal histopathology of fish kidneys (A) [22] ; Histology of tilapia kidneys damaged by necrosis $(\mathrm{N})$, cell degeneration $(\mathrm{Dg})$, congestion $(\mathrm{Kg})(\mathrm{B})$ (Source: Research documentation)

The ordinary fish kidney tissue structure, the distal tubule $(A)$, glomerulus $(B)$, and proximal tubule $(\mathrm{C})$, are visible (Figure $2 \mathrm{~A}$ ). Meanwhile, the results of observations on the structure of the kidney organs exposed to heavy metal Cd obtained types of damage in the form of necrosis, cell degeneration, and congestion (Figure 2B). Histological changes generally in tilapia kidney tissue are necrosis, congestion and cell degeneration [23]. Necrosis is damage that can result in tissue cell death characterized by the loss of cell boundaries, and cell nuclei [24]. Cell degeneration is a disorder due to a space characterized by swelling of the tubular epithelium [16]. Congestion is the damming of blood in which the volume of blood in the blood vessels increases [25].

Histopathological analysis result of tilapia (Oreochromis niloticus) liver was carried microscopically from each station are as follows (Table 3 ).

Table 3 - Histopathological Scoring of Tilapia (Oreochromis niloticus) Liver

\begin{tabular}{llllll}
\hline \multirow{2}{*}{ Station } & Damage & & & Average (\%) & \\
\cline { 2 - 5 } & Necrosis & Degeneration & Congestion & & Damage Status \\
\hline 1 & 25.33 & 72.33 & 40.33 & 46.00 & Mild \\
2 & 47.33 & 65.00 & 47.33 & 53.22 & Moderate \\
3 & 53.67 & 63.67 & 22.00 & 46.44 & Mild \\
\hline
\end{tabular}

Based on the observation result was made, the highest level of damage to liver tissue was found at station 2 with a harm percentage of $53.22 \%$ with moderate damage status, while the lowest gill tissue damage was at station 1 with a damage percentage of $46.00 \%$ with mild damage status. Based on analysis result of the damage statuses. It indicates that the liver of tilapia (Oreochromis niloticus) in the waters of the Lower Rejoso River that damaged due to exposure to pollutants, one of which is heavy metal Cd. Histopathology in fish livers can be used as an indicator of the toxicity of hazardous chemicals in waters [20]. The liver exposed to pollutants will experience damage to its tissue structure [26].

Generally, fish liver tissue structure, the hepatocytes $(H)$, central vein $(C V)$, and sinusoids (BS) were clearly visible (Figure 3A). Meanwhile, the results of observations on the structure of the liver exposed to heavy metal $\mathrm{Cd}$ obtained types of damage in the form of necrosis, cell degeneration and congestion (Figure 3B). Histological changes that occur in liver tissue in the form of necrosis and cell degeneration are caused by the presence of heavy metals in the waters [27]. Necrotic damage to fish liver can be characterized by loss of tissue structure [28]. Degenerative damage to the liver of fish characterizes by the presence of swollen tissue [20]. Furthermore, cells that experience continuous degeneration will later experience congestion damage, namely an increase in blood in the blood veins [15]. 
The measurement result of the physical and chemical parameters of water during the study can be seen in the table below (Table 4).

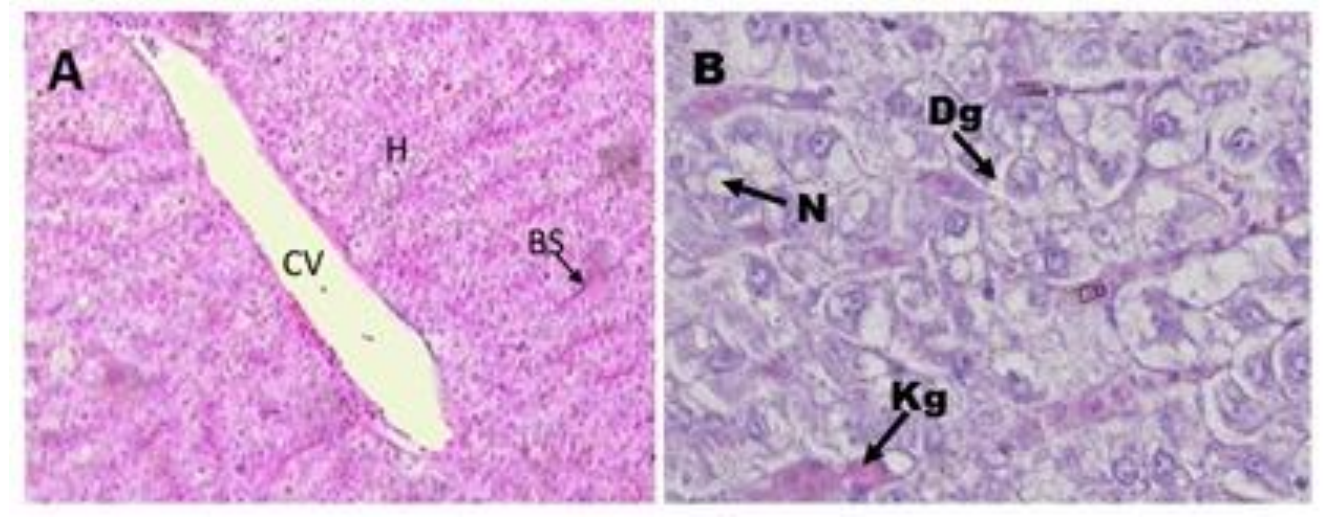

Figure 3 - Normal histopathological fish liver (A) [15] ; Histology of tilapia liver damaged Necrosis (N), Cell degeneration $(\mathrm{Dg})$, Congestion $(\mathrm{Kg})(\mathrm{B})$ (Source: Research documentation)

Table 4 - Physical and Chemical Parameters value of downstream in the Rejoso River

\begin{tabular}{|c|c|c|c|c|c|}
\hline \multirow{2}{*}{ Parameter } & \multirow[b]{2}{*}{ Unit } & \multirow{2}{*}{ PP No.22 of 2021 Class III quality standard } & \multicolumn{3}{|c|}{ Station } \\
\hline & & & 1 & 2 & 3 \\
\hline Temperature & ${ }^{\circ} \mathrm{C}$ & $28-30$ & 27.5 & 28.4 & 28.8 \\
\hline $\mathrm{pH}$ & & $6-9$ & 6.9 & 6.7 & 7.1 \\
\hline DO & $\mathrm{mg} / \mathrm{L}$ & 3 & 3.7 & 4.3 & 3.8 \\
\hline COD & $\mathrm{mg} / \mathrm{L}$ & 40 & 27.5 & 26.8 & 24.3 \\
\hline $\mathrm{Cd}$ & $\mathrm{mg} / \mathrm{L}$ & 0.01 & 0.14 & 0.06 & 0.17 \\
\hline
\end{tabular}

Temperature is one of the important indicators in waters. The temperature in the downstream area of the river is relatively higher because the intensity of sunlight is more in the downstream area [29]. The results of temperature measurements during the study ranged from $27.5-28.8^{\circ} \mathrm{C}$ (Table 4). The temperature value is still considered optimal for the growth of tilapia (Oreochromis niloticus). Differences in temperature in a waters can have an effect on fish organ tissues [30]. The optimum temperature for the growth and development of tilapia ranges from $20-30^{\circ} \mathrm{C}$. Some tilapia cannot survive at temperatures below $20^{\circ} \mathrm{C}$ [31].

The $\mathrm{pH}$ value can use as a determinant of the goodness or badness of water. The low $\mathrm{pH}$ value of the river is caused by the increasing amount of heavy metal content that enters the river waters [32]. The results of $\mathrm{pH}$ measurements during the study ranged from 6.7 to 7.1 (Table 4). The $\mathrm{pH}$ value is still in optimum conditions for the growth of tilapia (Oreochromis niloticus). The optimum $\mathrm{pH}$ value for tilapia ranges from 6.5 to 8.5. Waters having a pH value of $<4.8$ and $>9.8$ are classified as polluted waters [33].

Dissolved oxygen parameters can be used as an indicator of water quality because dissolved oxygen plays a role in the oxidation and reduction of organic and inorganic materials [34]. The measurement result of dissolved oxygen (DO) levels during the study ranged from 3.7 to $4.3 \mathrm{mg} / \mathrm{L}$ (Table 4). The dissolved oxygen level is still considered optimal for fish growth. Based on the Government Regulation of the Republic of Indonesia No. 22 of 2021 Class III, the minimum value for dissolved oxygen is $3 \mathrm{mg} / \mathrm{L}$. Low levels of dissolved oxygen in the water can interfere with the respiration process and reduce the level of activity of aquatic organisms. The decrease in dissolved oxygen levels in the impact human activities and increases water temperatures [35].

The results of measuring COD (Chemical Oxygen Demand) levels during the study ranged from 24.3-27.5 mg/L (Table 4). The COD value is still considered optimal for fish growth. Based on Government Regulation of the Republic of Indonesia No.22 of 2021 Class III, the optimal COD value for fish growth is $40 \mathrm{mg} / \mathrm{L}$. The high value of COD in water indicates that the water is polluted. It can interfere with the survival of the organisms on it [36]. 
Heavy metal Cadmium $(\mathrm{Cd})$ is a type of pollutant found in river waters. The analysis result of the heavy metal content of Cadmium (Cd) during the study ranged from 0.06-0.17 $\mathrm{mg} / \mathrm{L}$ (Table 4). The highest Cd value is at station 3, while the lowest $\mathrm{Cd}$ value is at station 2. Based on the Indonesian Government Regulation No.22 of 2021 for metal levels, the weight of $\mathrm{Cd}$ in the Lower Rejoso River has exceeded the Class III water quality standard, which is $0.01 \mathrm{mg} / \mathrm{L}$. The high value of $\mathrm{Cd}$ at station 3 is because the location included a residential area and rice fields. Sources of heavy metal pollution do not only come industrial waste but also from domestic waste, agriculture, and rice fields [35]. This is following the statement of [37], that pollution that occurs in river waters comes from the increasing amount of waste such as domestic waste, combustion emissions, mining activities, and agricultural activities.

The analysis result of of Cadmium (Cd) content in the gills, kidneys and liver of tilapia (Oreochromis niloticus) in the Lower Rejoso River can see in the table below (Table 5).

Table 5 - Heavy Metal Concentration of Cadmium (Cd) in Tilapia (Oreochromis niloticus) Organs

\begin{tabular}{lllll}
\hline \multirow{2}{*}{ No } & \multirow{2}{*}{ Organs } & Station & 2 & 3 \\
\cline { 3 - 5 } & & 1 & $2.73 \pm 0.12$ & $3.12 \pm 0.06$ \\
\hline 1 & Gill & $3.77 \pm 0.00$ & $16.83 \pm 0.10$ & $20.34 \pm 0.12$ \\
2 & Kidney & $18.49 \pm 0.08$ & $30.67 \pm 0.85$ & $29.69 \pm 0.34$ \\
3 & Liver & $26.58 \pm 0.27$ & & \\
\hline
\end{tabular}

The concentration of heavy metal $\mathrm{Cd}$ in the gills, kidneys, and liver of tilapia (Oreochromis niloticus) from each station has exceeded the threshold value based on SNI 7387:2009 The Maximum Limit of Heavy Metal Contamination in Food is $0.10 \mathrm{mg} / \mathrm{Kg}$. Tilapia (Oreochromis niloticus) that lives in the Lower Rejoso River is not suitable for human consumption. Fish containing high levels of heavy metals and exceeding the threshold was used as an indicator of pollution in water [38].

Heavy metal $\mathrm{Cd}$ enters the fish body in several ways, namely through the gill membranes (breathing), the food chain (digestion), and the mucous layer [39]. Usually, the heavy metal content in the fish body is higher than the heavy metal content in the waters [40]. Heavy metal Cd becomes dangerous in the body of fish or other aquatic organisms due to the bioaccumulation process [11].

\section{CONCLUSION}

Based on the analysis of the histopathology of the gills, kidneys, and liver of tilapia (Oreochromis niloticus) in the Lower Rejoso River, several types of damage were found namely cell degeneration, necrosis, congestion, and hyperplasia. The damage status of the three organs was in the light-moderate level of damage. This research supports the analysis result of the heavy metal content of $\mathrm{Cd}$ in the water and the organs of tilapia (Oreochromis niloticus) downstream in the Rejoso River that has exceeded the quality standard. With the increasing $\mathrm{Cd}$ content in river waters, the histopathological damage to fish organs will also increase

\section{ACKNOWLEDGEMENTS}

This research can be carried out well thanks to the assistance of various parties involved. The researcher would like to thank the supervisors, the community around the Rejoso River, and the fishermen who have helped in the research implementation.

\section{REFERENCES}

1. Ustaoğlu F., Y. Tepe, and B. Taş, "Assessment of stream quality and health risk in a subtropical Turkey river system: A combined approach using statistical analysis and water quality index," Ecol. Indic., vol. 113, p. 105815, 2020, doi: 10.1016/j.ecolind.2019.105815. 
2. Ustaoğlu F. and Y. Tepe, "Water quality and sediment contamination assessment of Pazarsuyu Stream, Turkey using multivariate statistical methods and pollution indicators," Int. Soil Water Conserv. Res., vol. 7, no. 1, pp. 47-56, 2019, doi: 10.1016/j.iswcr.2018.09.001.

3. Muryani C., "Analysis of Coastline Changes Using GIS and its Impact on The Community's Life Around Rejoso River Estuary Pasuruan District," Geogr. Forum J., vol. 24, no. 2, pp. 173-182, 2010.

4. Dalu T., R. J. Wasserman, M. L. Magoro, T. Mwedzi, P. W. Froneman, and O. L. F. Weyl, "Variation partitioning of benthic diatom community matrices: Effects of multiple variables on benthic diatom communities in an Austral temperate river system," Sci. Total Environ., vol. 601-602, pp. 73-82, 2017, doi: 10.1016/j.scitotenv.2017.05.162.

5. Karbassi A. R., S. M. Monavari, G. R. Nabi Bidhendi, J. Nouri, and K. Nematpour, "Metal Pollution Assessment of Sediment and Water in The Shur River," Environ. Monit. Assess., vol. 147, no. 1, pp. 107-116, 2008, doi: 10.1007/s10661-007-0102-8.

6. Afshan S. et al., "Effect of different heavy metal pollution on fish," Res. J. Chem. Environ. Sci., vol. 2, no. 1, pp. 74-79, 2014.

7. Mamoribo H., R. J. Rompas, and O. J. Kalesaran, "Determination of Cadmium Content (Cd) in Malalayang Coastal Waters Around Hospital Prof Kandou Manado," J. Aquac., vol. 3, no. 1, pp. 114-118, 2015, doi: 10.35800/bdp.3.1.2015.6945.

8. Zeitoun M. M. and E. S. E. Mehana, "Impact of water pollution with heavy metals on fish health: Overview and updates," Glob. Vet., vol. 12, no. 2, pp. 219-231, 2014, doi: 10.5829/idosi.gv.2014.12.02.82219.

9. Elgaml S. A., T. T. Saad, M. F. Hamed, and V. H. Zaki, "Effects of heavy metal pollutants on the reproduction of Nile tilapia," Int. J. Fish. Aquat. Stud. IJFAS, vol. 7, no. 5, pp. 542547, 2019.

10. Wandari D. W. T., I. W. Restu, and E. W. Suryaningtyas, "The Study of Histopatology Gill Tilapia (Oreochromis niloticus, Linn.) in Terms of Levels of Ammonia (NH3) in Batur Lake, Bali," J. Biol. Sci., vol. 5, no. 1, pp. 1-7, 2018.

11. Bose M. T. J., M. llavazhahan, R. Tamilselvi, and M. Viswanathan, "Effect of heavy metals on the histopathology of gills and brain of fresh water fish Catla catla," Biomed. Pharmacol. J., vol. 6, no. 1, pp. 99-105, 2013, doi: 10.13005/bpj/390.

12. McHugh K. J. et al., "A histology-based fish health assessment of the tigerfish, Hydrocynus vittatus from a DDT-affected area," Phys. Chem. Earth, vol. 36, no. 14-15, pp. 895-904, 2011, doi: 10.1016/j.pce.2011.07.077.

13. Peraturan Pemerintah Nomor 22 Tahun 2021, "Penyelenggaraan Perlindungan dan Pengelolaan Lingkungan Hidup," Sekertariat. Negara Republik Indonesia., vol. 1, p. 483, 2021.

14. SNI 7387:2009, "Batas Maksimum Cemaran Logam Berat dalam Pangan," Batas Maksimum Cemaran Logam Berat dalam Pangan, p. 17, 2009.

15. Hadi A. A. and S. F. Alwan, "Histopathological changes in gills, liver and kidney of fresh water fish, Tilapia zillii, exposed to aluminum," Int. J. Pharm. Life Sci., vol. 3, no. 11, pp. 2071-2081, 2012.

16. Ibrahim S. A., "Effect of water quality changes on gills and kidney histology of Oreochromis niloticus fish inhabiting the water of Rosetta branch, River Nile, Egypt," World Appl. Sci. J., vol. 26, no. 4, pp. 438-448, 2013, doi: 10.5829/idosi.wasj.2013.26.04.76159.

17. Afifi M., A. Alkaladi, O. Abu-Zinada, and N. Z. Zahed, "Histopathological and ultrastractural alterations in skin, gills, liver and muscle of Siganus canaliculatus and Epinephelus morio caught from Jeddah and Yanbu coast as bio-indicators of oil hydrocarbons pollution," Life Sci. J., vol. 11, no. 8, pp. 880-888, 2014.

18. Arockia Vasanthi L., P. Revathi, C. Arulvasu, and N. Munuswamy, "Biomarkers of metal toxicity and histology of Perna viridis from Ennore estuary, Chennai, south east coast of India," Ecotoxicol. Environ. Saf., vol. 84, pp. 92-98, 2012, doi: 10.1016/j.ecoenv.2012.06.025. 
19. Kaoud A., H aEl-Dahshan, "Bioaccumulation and histopathological alterations of the heavy metals in Oreochromis niloticus fish," Nat. Sci., vol. 8, no. 4, pp. 147-156, 2010.

20. Kalaiyarasi T., N. Jayakumar, P. Jawahar, B. Ahilan, and A. Subburaj, "Histological changes in the gill and liver of marine spotted catfish, Arius maculatus from sewage disposal site, Therespuram off Thoothukudi, Southeast coast of India," J. Entomol. Zool. Stud., vol. 5, no. 5, pp. 1710-1715, 2017.

21. Thophon S., M. Kruatrachue, E. S. Upatham, P. Pokethitiyook, S. Sahaphong, and S. Jaritkhuan, "Histopathological alterations of white seabass, Lates calcarifer, in acute and subchronic cadmium exposure," Environ. Pollut., vol. 121, no. 3, pp. 307-320, 2003, doi: 10.1016/S0269-7491(02)00270-1.

22. Apriliani N. S. and M. J. Luthfi, "Comparative Anatomy and Histology of Black Pomfret (Formio niger) and Nile tilapia (Oreochromis niloticus) Kidney," Biol. Med. Nat. Prod. Chem., vol. 6, no. 1, pp. 9-12, 2017, doi: 10.14421/biomedich.2017.61.9-12.

23. Wolf J. C. et al., "Nonlesions, Misdiagnoses, Missed Diagnoses, and Other Interpretive Challenges in Fish Histopathology Studies:A Guide for Investigators, Authors, Reviewers, and Readers," Toxicol. Pathol., vol. 43, no. 3, pp. 297-325, 2015, doi: 10.1177/0192623314540229.

24. Lubis U. F., N. Marusin, and I. J. Zakaria, "Analisis Histologis Hati Ikan Asang (Osteochilus hasseltii CV) di Danau Maninjau dan Danau Singkarak, Sumatera Barat," J. Biol. UNAND, vol. 3, no. 2, pp. 162-167, 2014.

25. Ramesh M., S. Anitha, R. K. Poopal, and C. Shobana, "Evaluation of acute and sublethal effects of chloroquine ( $\mathrm{C} 18 \mathrm{H} 26 \mathrm{CIN} 3)$ on certain enzymological and histopathological biomarker responses of a freshwater fish Cyprinus carpio," Toxicol. Reports, vol. 5, pp. 18-27, 2018, doi: 10.1016/j.toxrep.2017.11.006.

26. Marchand M. J., J. C. van Dyk, I. E. J. Barnhoorn, and G. M. Wagenaar, "Histopathological changes in two potential indicator fish species from a hyper-eutrophic freshwater ecosystem in South Africa: A baseline study," African J. Aquat. Sci., vol. 37, no. 1, pp. 39-48, 2012, doi: 10.2989/16085914.2011.636902.

27. Jannah R., Rosmaidar, Nazaruddin, Winaruddin, U. Balqis, and T. Armansyah, "Pengaruh Paparan Timbal $(\mathrm{Pb})$ terhadap Histopatologi Hati Ikan Nila (Oreochromis nilloticus)," JIMVET, vol. 1, no. 4, pp. 742-748, 2017.

28. Juanda S. J. and S. I. Edo, "Gill, Liver and Gut's Histopathology of Catfish (Clarias gariepinus) in Kota Kupang, East West Nusa," Indones. J. Fish. Sci. Technol., vol. 14, no. 1, pp. 23-29, 2018, doi: 10.14710/ijfst.14.1.23-29.

29. Secchi S., P. W. Gassman, M. Jha, L. Kurkalova, and C. L. Kling, "Potential water quality changes due to corn expansion in the Upper Mississippi River Basin," Ecol. Appl., vol. 21, no. 4, pp. 1068-1084, 2011, doi: 10.1890/09-0619.1.

30. Sumantri A., M. Mulyana, and F. S. Mumpuni, "Pengaruh Perbedaan Suhu Pemeliharaan Terhadap Histopatologi Insang Dan Kulit Ikan Komet (Carassius auratus)," J. Mina Sains, vol. 3, no. 1, pp. 1-7, 2017, doi: 10.30997/jms.v3i1.866.

31. Mjoun K., K. Rosentrater, and M. L. Brown, "TILAPIA : Profile and Economic Importance," South Dakota Coop. Ext. Serv., pp. 1-5, 2010.

32. Mosley L. M., R. W. Fitzpatrick, D. Palmer, E. Leyden, and P. Shand, "Changes in acidity and metal geochemistry in soils, groundwater, drain and river water in the Lower Murray River after a severe drought," Sci. Total Environ., vol. 485-486, no. 1, pp. 281-291, 2014, doi: 10.1016/j.scitotenv.2014.03.063.

33. Amal M. N. A., M. Z. Saad, A. S. Zahrah, and A. R. Zulkafli, "Water quality influences the presence of Streptococcus agalactiae in cage cultured red hybrid tilapia, Oreochromis niloticus $\times$ Oreochromis mossambicus," Aquac. Res., vol. 46, no. 2, pp. 313-323, 2015, doi: $10.1111 /$ are.12180.

34. Huang Y., D. Zhang, Z. Xu, S. Yuan, Y. Li, and L. Wang, "Effect of overlying water pH, dissolved oxygen and temperature on heavy metal release from river sediments under laboratory conditions," Arch. Environ. Prot., vol. 43, no. 2, pp. 28-36, 2017, doi: 10.1515/aep-2017-0014. 
35. Blume K. K., J. C. Macedo, A. Meneguzzi, L. B. Silva, D. M. Quevedo, and M. A. S. Rodrigues, "Water quality assessment of the Sinos River, Southern Brazil," Brazilian J. Biol., vol. 70, no. 4, pp. 1185-1193, 2010, doi: 10.1590/s1519-69842010000600008.

36. C. E. Boyd, Water Quality An Introduction Third Edition, no. Springer. 2015.

37. Farombi E. O., O. A. Adelowo, and Y. R. Ajimoko, "Biomarkers of oxidative stress and heavy metal levels as indicators of environmental pollution in African cat fish (Clarias gariepinus) from Nigeria Ogun River," Int. J. Environ. Res. Public Health, vol. 4, no. 2, pp. 158-165, 2007, doi: 10.3390/ijerph2007040011.

38. Sundari D., M. Hananto, and S. Suharjo, "Kandungan Logam Berat dalam Bahan Pangan di Kawasan Industri Kilang Minyak, Dumai," Bul. Penelit. Sist. Kesehat., vol. 19, no. 1, pp. 55-61, 2016, doi: 10.22435/hsr.v19i1.4989.55-61.

39. Gaber H. S., M. A. El-Kasheif, S. A. Ibrahim, and M. M. N. Authman, "Effect of water pollution in El-Rahawy drainage canal on hematology and organs of freshwater fish Clarias gariepinus," World Appl. Sci. J., vol. 21, no. 3, pp. 329-341, 2013, doi: 10.5829/idosi.wasj.2013.21.3.71192.

40. Istarani F. and E. S. Pandebestie, "Studi Dampak Arsen (As) dan Kadmium (Cd) terhadap Penurunan Kualitas Lingkungan,” J. Tek. Pomits, vol. 3, no. 1, pp. 1-6, 2014. 